\title{
Common Risks Affecting Time Overrun in Road Construction Projects in Palestine: Contractors' Perspective
}

Ibrahim Mahamid (Hail University, Kingdom of Saudi Arabia)

\begin{abstract}
The construction sector is one of the key economic sectors and is the main force motivating the Palestinian national economy. However, it suffers from a number of problems that affect time, cost and quality performances. This study aims at identifying the common risks affecting time overrun in road construction projects in the West Bank in Palestine from contractors' viewpoint. 45 factors that might cause delays of road construction projects were defined through a detailed literature review. A questionnaire survey was performed to rank the considered factors in terms of severity and frequency. The analysis of the survey indicated that the top risks affecting time overrun in road construction projects in Palestine are: financial status of the contractors, payment delays by the owner, the political situation and segmentation of the West Bank, poor communication between construction parties, lack of equipment efficiency and high competition in bids.
\end{abstract}

Keywords: Contractors, Road construction, Time overrun, Risk map, Delay

\section{Introduction}

The construction sector is one of the key economic sectors and is the main force motivating the Palestinian national economy. Upon the establishment of the Palestinian National Authority (PNA) and the assumption of its power over the Palestinian territories in 1994, the construction sector has witnessed noticeable expansion and activities. This has resulted in the recovery of the construction contracting profession and subsidiary industries, encouraged the investment of Palestinian expatriates in the local construction sector and contributed to the creation of jobs for thousands of Palestinians. Therefore, the construction sector has occupied a very important position relative to the rest of the economy, attracting investments and creating new jobs (Palestinian Contractors Union (PCU), 2003/1). The Palestinian Central Bureau of Statistics (PCBS) shows that the construction sector contribution to the Palestinian GDP has increased since the PNA establishment to reach $11.1 \%$ of the Palestinian GDP in 2010. This is a large proportion that positively affect various other economic, social, educational and vocational sectors and Palestinian institutions (PCBS, 2011/1).

In spite of the high importance of construction sector in Palestine, the industry suffers from a number of problems that affect time, cost and quality performances. Mahamid and Bruland (2012) concluded that all road construction projects implemented in the West Bank during 2004 -2008 experienced cost overrun. Mahamid et al. (2011) conducted a study to investigate the time delay in road construction projects in the West Bank in Palestine, they found that all projects suffer from time overrun and that $70 \%$ of the projects experienced delays between $10 \%$ and $30 \%$ of the contracted duration. Therefore, attention should be paid to this important sector in order to identify its main challenges and control them. This study aims at identifying the common risks affecting time overruns in road construction projects in the West Bank in Palestine and map the risks from the contractors' point of view. It is hoped that the findings of 
this study will provide a solid overview and guide efforts to enhance the performance of the construction industry.

\section{Literature Review}

Many studies have been conducted to identify the causes of delay in construction projects. Chan et al. (1997) indicated that the five principal causes of delays in Hong Kong construction projects are: poor site management and supervision, unforeseen ground conditions, low speed of decision making involving all project teams, client-initiated variations and necessary variations of works.

In a survey of the West Bank in Palestine, Mahamid (2011) indicated that the most severe factors affecting time delay in road construction projects from the owners' perspective are: poor communication between construction parties, poor resource management, delays in commencement, insufficient inspectors, and rework. Similarly, Al-Najjar (2008) concluded that the most important factors causing time overruns in building construction projects in the Gaza Strip as perceived by contractors were: strikes, Israeli attacks and border closures, lack of materials in the markets, shortage of construction materials at site, delays of material deliveries to site, cash shortages during construction, poor site management, poor economic conditions (currency, inflation rate, etc), shortage of equipment and tools on site, and owner delay in freeing the contractors payments for completed work.

Examining the factors that cause delay in construction projects in Malaysia, Alghbari et al. (2007) tested 31 variables. The main finding of the study was that financial factors are the most common cause of delays in construction projects in Malaysia. Coordination problems are considered the second most important factor causing delays, followed by materials problems.

Al-Momani (2000) investigated causes of delay in 130 public building projects constructed in Jordan during the period of 1990-1997. He concluded that the main causes of delay are related to designer or user changes, weather, site conditions, late deliveries, economic conditions and increases in quantities. Also in Malaysia, Sambasivan and Soon (2007) concluded that the ten most important causes of delays the construction industry were: contractor's improper planning, contractor's poor site management, inadequate contractor experience, inadequate client's finance and payments for completed work, problems with subcontractors, shortage in material, labor shortages, equipment availability and failure, lack of communication between parties, and mistakes during the construction stage.

An interview survey of 450 randomly selected private residential project owners and developers by Koushki et al (2005) found that the main causes of delays in Kuwait were changing orders, owners' financial constraints and owners' lack of experience. Faridi and El-sayegh (2006) studied the delay in construction projects in UAE and concluded that $50 \%$ of the construction projects encounter delays and are not completed on time. The most significant causes of construction delays are approval of drawings, inadequate early planning and delays in the owners' decision-making process.

\section{Research Methodology}

45 factors that might cause delays of road construction projects were defined through this literature review. The factors were tabulated in a questionnaire form. The questionnaire was divided into two main parts. Part I related to general information about the contractors' companies and the respondents' experience in the construction industry. Part II included the list of the identified causes of delay in road construction projects. These causes were classified into 6 groups according to the sources of delay: project, managerial, consultant, external,

Mahamid I (2013) 'Common risks affecting time overrun in road construction projects in Palestine: Contractors' perspective', Australasian Journal of Construction Economics and Building, 13 (2) 45-53 
construction items, and financial. For each factor two questions were asked: "what is the frequency of occurrence for this cause?" and "what is the degree of severity of this cause on project delay?" Both frequency of occurrence and severity were categorized according to Table 1.

\begin{tabular}{|c|c|c|}
\hline Scale & Severity & Frequency of occurrence \\
\hline $20 \%$ & very low $(\mathrm{VL})$ & very low $(\mathrm{VL})$ \\
\hline $20 \%-40 \%$ & low $(\mathrm{L})$ & low $(\mathrm{L})$ \\
\hline $40 \%-60 \%$ & moderate $(\mathrm{M})$ & moderate $(\mathrm{M})$ \\
\hline $60 \%-80 \%$ & high $(\mathrm{H})$ & high $(\mathrm{H})$ \\
\hline $80 \%-! 00 \%$ & very high $(\mathrm{VH})$ & very high $(\mathrm{VH})$ \\
\hline
\end{tabular}

Table 1 Scale used to identify factor's severity and frequency of occurrence

The average value for responses to each factor is calculated to find out its severity degree and frequency of occurrence. Then, the risk map for factors affecting time overrun in road construction projects in the West Bank was developed based on Figure 1. The map is a $5 \times 5$ matrix with severity ranging from $\mathrm{VL}$ to $\mathrm{VH}$ on the horizontal axis and frequency (with the same range) on the vertical axis (The U.S. Federal Highway Administration Office of International Programs, 2007).

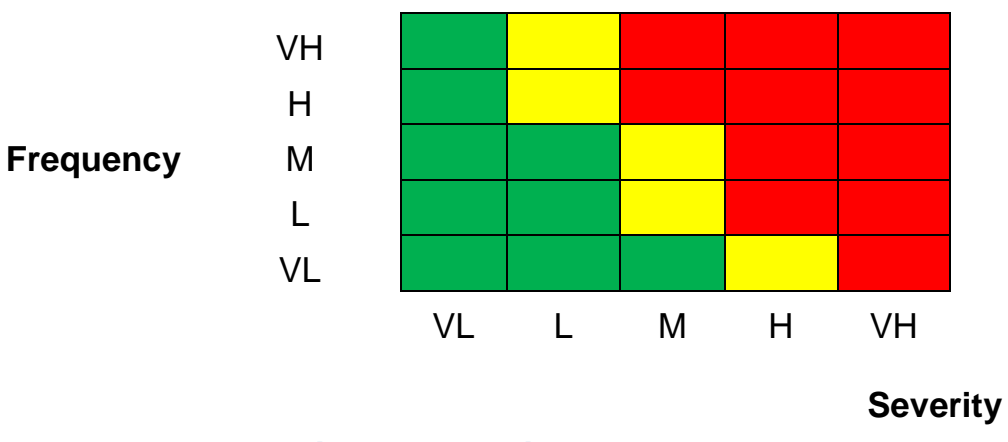

Figure 1 The risk map

The map is classified into three zones:

- Green zone: risks in this zone are low level, and can be ignored.

- Yellow zone: risks in this zone are of moderate importance, and should be controlled.

- Red zone: risks in this zone are of critical importance, and a close attention should be paid.

The questionnaire was sent out to a total of 41 contracting firms asking their contribution in identifying the risk map for the 45 factors in terms of severity and frequency of occurrence. The contractors were randomly selected from available list in PCU including 50 contractors. Only a total of 34 completed questionnaires were returned representing a response rate of $83 \%$. Most of the participating contractors have more than 10 years of experience in road construction.

\section{Results and Discussion}

In this study, the risk map for 45 factors that might cause time delays in road construction projects in the West Bank was identified. These factors were classified into 6 groups: project, managerial, consultant, financial, external, and construction items. The risk map for factors under each group is identified in tables $2-7$ below. 


\section{Project Group}

Table 2 illustrates the risk map for factors under project group. Six factors are considered under this group. The results indicate that three factors are located in the yellow zone, namely: inconvenient site access, disturbance to public activities, and limited construction area. The other three factors are located in the green zone, they are: poor terrain condition, poor soil drillability, and poor soil suitability.

\begin{tabular}{|l|c|c|c|}
\hline \multicolumn{1}{|c|}{ Factors } & Severity & Frequency & Map zone \\
\hline inconvenient site access & $\mathrm{M}$ & $\mathrm{M}$ & yellow \\
\hline disturbance to public activities & $\mathrm{M}$ & $\mathrm{M}$ & yellow \\
\hline limited construction area & $\mathrm{M}$ & $\mathrm{M}$ & yellow \\
\hline poor terrain condition & $\mathrm{L}$ & $\mathrm{L}$ & green \\
\hline poor soil drillability & $\mathrm{L}$ & $\mathrm{L}$ & green \\
\hline poor soil suitability & $\mathrm{L}$ & $\mathrm{L}$ & green \\
\hline
\end{tabular}

Table 2 Risk map for factor under project group

\section{Managerial Group}

Table 3 illustrates the risk map for factors under managerial group. Fifteen factors are considered under this group. The results indicate that two factors are located in the red zone; they are: poor communication between construction parties, and high competition in bids. The other factors under this group are located in the yellow zone.

\begin{tabular}{|l|c|c|c|}
\hline \multicolumn{1}{|c|}{ Factors } & Severity & Frequency & Map zone \\
\hline $\begin{array}{l}\text { poor communication between construction } \\
\text { parties }\end{array}$ & $\mathrm{H}$ & $\mathrm{M}$ & red \\
\hline delays in decision making & $\mathrm{M}$ & $\mathrm{M}$ & yellow \\
\hline unreasonable project time frame & $\mathrm{M}$ & $\mathrm{M}$ & yellow \\
\hline internal administrative problems & $\mathrm{M}$ & $\mathrm{M}$ & yellow \\
\hline undefined scope of working & $\mathrm{M}$ & $\mathrm{M}$ & yellow \\
\hline improper construction method & $\mathrm{M}$ & $\mathrm{M}$ & yellow \\
\hline resource management & $\mathrm{M}$ & $\mathrm{M}$ & yellow \\
\hline late land hand-over & $\mathrm{M}$ & $\mathrm{L}$ & yellow \\
\hline delay in commencement & $\mathrm{M}$ & $\mathrm{M}$ & yellow \\
\hline late documentation & $\mathrm{M}$ & $\mathrm{M}$ & yellow \\
\hline late submission of nominated materials & $\mathrm{M}$ & $\mathrm{M}$ & yellow \\
\hline postponement of project & $\mathrm{M}$ & $\mathrm{M}$ & yellow \\
\hline late issuing of approval documents & $\mathrm{M}$ & $\mathrm{L}$ & yellow \\
\hline high competition in bids & $\mathrm{H}$ & $\mathrm{M}$ & red \\
\hline changes in management ways & $\mathrm{M}$ & $\mathrm{M}$ & yellow \\
\hline
\end{tabular}

Table 3 Risk map for factors under managerial group

Mahamid I (2013) 'Common risks affecting time overrun in road construction projects in Palestine: Contractors' perspective', Australasian Journal of Construction Economics and Building, 13 (2) 45-53 


\section{Consultant Group}

Table 4 illustrates the risk map for factors under the consultant group. Eight factors are considered under this group. The results indicate that all factors under this group are located in the yellow zone.

\begin{tabular}{|l|c|c|c|}
\hline \multicolumn{1}{|c|}{ Factors } & Severity & Frequency & Map zone \\
\hline mistakes in design & $\mathrm{M}$ & $\mathrm{M}$ & yellow \\
\hline design changes & $\mathrm{M}$ & $\mathrm{M}$ & yellow \\
\hline inappropriate design & $\mathrm{M}$ & $\mathrm{M}$ & yellow \\
\hline late inspection & $\mathrm{M}$ & $\mathrm{M}$ & yellow \\
\hline late approval & $\mathrm{M}$ & $\mathrm{M}$ & yellow \\
\hline insufficient inspectors & $\mathrm{M}$ & $\mathrm{L}$ & yellow \\
\hline late design works & $\mathrm{M}$ & $\mathrm{M}$ & yellow \\
\hline incapable inspectors & $\mathrm{M}$ & $\mathrm{L}$ & yellow \\
\hline
\end{tabular}

Table 4 Risk map for factors under consultant group

\section{Financial Group}

Table 5 illustrates the risk map for factors under the financial group. Seven factors are considered under this group. The results indicate that 2 factors under this group are located in the red zone, they are: payments delay by the owner, and financial status of the contractor. The results also indicate that 2 factors under this group are located in the yellow zone, and 3 factors in the green zone.

\begin{tabular}{|l|c|c|c|}
\hline \multicolumn{1}{|c|}{ Factors } & Severity & Frequency & Map zone \\
\hline payments delay by the owner & $\mathrm{H}$ & $\mathrm{H}$ & red \\
\hline financial status of contractor & $\mathrm{H}$ & $\mathrm{M}$ & red \\
\hline financial status of owner & $\mathrm{M}$ & $\mathrm{M}$ & yellow \\
\hline exchange rate fluctuation & $\mathrm{M}$ & $\mathrm{M}$ & yellow \\
\hline changing of bankers policy for loans & $\mathrm{L}$ & $\mathrm{L}$ & green \\
\hline inflation & $\mathrm{L}$ & $\mathrm{L}$ & green \\
\hline monopoly & $\mathrm{L}$ & $\mathrm{L}$ & green \\
\hline
\end{tabular}

Table 5 Risk map for factors under financial group

\section{External Group}

Table 6 illustrates the risk map for factors under external group. Four factors are considered under this group. The results show that the political situation and segmentation of the West Bank are the most important factors under this group and they are located in the red zone. The weather condition and natural disaster are located in the green zone. 


\begin{tabular}{|l|c|c|c|}
\hline \multicolumn{1}{|c|}{ Factors } & Severity & Frequency & Map zone \\
\hline political situation & $\mathrm{VH}$ & $\mathrm{VH}$ & red \\
\hline segmentation of the West Bank & $\mathrm{H}$ & $\mathrm{H}$ & red \\
\hline weather condition & $\mathrm{L}$ & $\mathrm{M}$ & green \\
\hline natural disaster & $\mathrm{VL}$ & $\mathrm{VL}$ & green \\
\hline
\end{tabular}

Table 6 Risk map for factors under external group

\section{Construction items Group}

Table 7 illustrates the risk map for factors under construction items group. Five factors are considered under this group. The results show that one factor in this group is located in the red zone: lack of equipment efficiency. The other 4 factors in this group are located in yellow zone of the risk map.

\begin{tabular}{|l|c|c|c|}
\hline \multicolumn{1}{|c|}{ Factors } & Severity & Frequency & Map zone \\
\hline insufficient labors & $\mathrm{M}$ & $\mathrm{M}$ & yellow \\
\hline rework from poor workmanship & $\mathrm{M}$ & $\mathrm{M}$ & yellow \\
\hline lack of equipment efficiency & $\mathrm{H}$ & $\mathrm{M}$ & red \\
\hline unavailable construction material & $\mathrm{M}$ & $\mathrm{L}$ & yellow \\
\hline rework from poor material quality & $\mathrm{M}$ & $\mathrm{L}$ & yellow \\
\hline
\end{tabular}

Table 7 Risk map for factors under construction items group

\section{The Critical Factors}

Table 8 shows the most critical factors affecting time overruns in road construction projects in the West Bank as well as related groups of factors and comparisons between the results of this study and the studies investigated in the literature review. In this study, 7 factors are found to be critical. These factors are discussed below:

1) Financial status of the contractors: one of the most common problems in construction contracting in Palestine is the policy of awarding the bid to the lowest bidder rather than to the most accurate. The owners award the contracts to lowest bidders, but sometimes the lowest bidder is a less well qualified contractor with low capabilities and resources which leads to poor performance and causes delays in completion of the work. To overcome this problem, the owner may check for the resources and capabilities of the bidders before accepting a bid or awarding the contract, or contracts could be awarded to the bid closest to the client's estimate of the cost and not necessarily to the lowest bidder. This result is supported by Al-Najjar (2008) and Alghbari et al. (2007).

2) Payment delays by the owner: construction works involve high daily expenses that can't be met by the contractors when progress payments by the owners are delayed. This affects the completion of works on time since many of the contracting firms in the West Bank are small with very limited cash reserves. This result is supported by many of the investigated studies (Al-Najjar, 2008; Alghbari et al., 2007; Sambasivan and Soon, 2007, Koushkis et al., 2005)

Mahamid I (2013) 'Common risks affecting time overrun in road construction projects in Palestine: Contractors' perspective', Australasian Journal of Construction Economics and Building, 13 (2) 45-53 
3) The political situation and 4) segmentations of the West Bank: the political situation in the West Bank is described as unstable because of the conflict between Israel and Palestine. As a result, the West Bank is segmented into many areas that restricts the movement of people, goods and services between these areas. High costs of material, lack of resources, limitations on material import, high level of taxes imposed by Israel, delays and monopolies are some other results of the political situation in the West Bank. All of these factors lead to time overruns in construction projects. This result is supported by Al-Najjar's study of the situation in Gaza (2008).

5) Poor communication between construction parties: this leads to estrangement between the parties and misunderstandings regarding the contract requirements. Thus, this result illustrates the importance of rising awareness among the contracting parties to ensure a culture of team work and to achieve their desires of a less adversarial working climate. This result is supported by several of the investigated studies (Mahamid, 2011; Alghbari et al., 2007; Sambasivan and Soon, 2007).

6) High competition in bids: due to the intense competition between contractors and few projects in relation to the number of contractors in the West Bank, some contractors burn the rates to win bids. In this regard, an accurate estimate of prices may be established by the owner to evaluate properly the tender price before awarding the tender. This may help to avoid awarding contracts to companies offering rates that might affect their ability to execute the project properly and safely. This result was not pointed out by any of the investigated studies.

7) Lack of equipment efficiency: many of the contracting firms in the West Bank are small with inadequate cash flow. Usually, they rent their equipment when required. When there are many construction projects, the equipment are in short supply and are poorly maintained. This leads to failure of the equipment causing projects to be delayed. This result was not pointed out by any of the investigated studies.

\begin{tabular}{|c|c|c|c|c|c|}
\hline $\begin{array}{l}\text { Critical factor } \\
\text { (this study) }\end{array}$ & Related group & Severity & Frequency & $\begin{array}{l}\text { Map } \\
\text { zone }\end{array}$ & $\begin{array}{l}\text { Comparison with the } \\
\text { investigated studies }\end{array}$ \\
\hline $\begin{array}{l}\text { financial status of the } \\
\text { contractor }\end{array}$ & financial & $\mathrm{H}$ & $M$ & red & $\begin{array}{l}\text { supported by Al-Najjar } \\
\text { (2008) and Alghbari et al. } \\
\text { (2007) }\end{array}$ \\
\hline $\begin{array}{l}\text { payments delay by the } \\
\text { owner }\end{array}$ & financial & $\mathrm{M}$ & $\mathrm{H}$ & red & $\begin{array}{l}\text { supported by (Al-Najjar, } \\
\text { 2008; Alghbari et al., 2007; } \\
\text { Sambasivan and Soon, } \\
\text { 2007, Koushkis et al., 2005) }\end{array}$ \\
\hline political situation & external & $\mathrm{H}$ & $\mathrm{H}$ & red & $\begin{array}{l}\text { supported by Al-Najjar } \\
(2008)\end{array}$ \\
\hline $\begin{array}{l}\text { segmentation of the } \\
\text { West Bank }\end{array}$ & external & $\mathrm{H}$ & $\mathrm{H}$ & red & $\begin{array}{l}\text { not concluded by any of the } \\
\text { investigated studies }\end{array}$ \\
\hline $\begin{array}{l}\text { poor communication } \\
\text { between construction } \\
\text { parties }\end{array}$ & managerial & $\mathrm{H}$ & $M$ & red & $\begin{array}{l}\text { supported by (Mahamid, } \\
\text { 2011; Alghbari et al., 2007; } \\
\text { Sambasivan and Soon, } \\
\text { 2007) }\end{array}$ \\
\hline high competition in bids & managerial & $\mathrm{H}$ & $M$ & red & $\begin{array}{l}\text { not concluded by any of the } \\
\text { investigated studies }\end{array}$ \\
\hline $\begin{array}{l}\text { lack of equipment } \\
\text { efficiency }\end{array}$ & $\begin{array}{l}\text { Construction } \\
\text { items }\end{array}$ & $\mathrm{H}$ & M & red & $\begin{array}{l}\text { not concluded by any of the } \\
\text { investigated studies }\end{array}$ \\
\hline
\end{tabular}

Table 8 Critical factors of this study and comparison with the investigated studies

Mahamid I (2013) 'Common risks affecting time overrun in road construction projects in Palestine: Contractors' perspective', Australasian Journal of Construction Economics and Building, 13 (2) 45-53 


\section{Conclusion}

The aim of this study was to identify the risk map for factors affecting time overrun in road construction projects in the West Bank in Palestine from contractors' viewpoint. The analysis of 45 factors considered in a survey indicates that 8 factors are located in the green zone (low frequency, low severity), 30 factors are in the yellow zone, and 7 factors in the red zone (high frequency, high severity) in the risk map. The most critical factors are: payment delays by the owner, the political situation, the segmentation of the West Bank, the financial status of the contractor, poor communication between the construction parties, lack of equipment efficiency and high competition in bids.

It can be seen that the most critical factors are due to both external and internal issues: the external being high competition, the political situation and segmentation of the West Bank. These factors can't be controlled by the construction parties but the government could reduce these problems to the benefit of all construction parties. The internal issues are: payment delays by owners, financial status of the contractors, poor communication between construction parties and low equipment efficiency. To improve the situation, attention should be paid to these factors, e.g. the owners should pay progress payments on time, the bids should be awarded to the contractors who are financially sound, the construction parties should have more communication and coordination during all project phases, and the managerial skills of the construction parties should be improved by conducting workshops and training courses.

The findings of this study show common critical factors between this study and the investigated studies, namely: financial status of the contractor, payments delay by the owner and poor communication between the construction parties. The contractors also have views on factors that have not been identified previously such as low equipment efficiency, high competitions in bids, and the political situation. This may be the effect of the political situation in the West Bank. The Israeli occupation and boarder control may have negatively affected the performance in construction projects in the West Bank in ways not encountered in other study areas such as: lack of equipment, difficulties in importing materials and new equipment and limitations on the movement of people and goods between the West Bank cities and villages.

\section{References}

Alghbari, W., Kadir, M., Salim, A. and Ernawati (2007) 'The significant factors causing delay of building construction projects in Malaysia', Journal of Engineering, Construction and Architectural Management, 14 (2), 192-206

Al-Momani, A. (2000) 'Construction delay: a quantitative analysis', International Journal of Project Management, 18 (1), 51-59

Al-Najjar, J. (2008) Factors influencing time and cost overruns on construction projects in the Gaza Strip, Islamic University, Gaza

Chan, Daniel W. and Kumaraswamy, Mohan M. (1997) 'A comparative study of causes of time overruns in Hong Kong construction projects', International Journal of Project Management, 15 (1), 55-63

Faridi, A. and El-sayegh, S. (2006) 'Significant factors causing delay in the UAE construction industry', Construction Management and Economics, 24, 1167-1176

Koushki, P., Al-Rashid, K., and Kartam, N. (2005) 'Delays and cost increases in the construction of private residential projects in Kuwait', Construction Management and Economics, 23 (3), 285294

Mahamid I (2013) 'Common risks affecting time overrun in road construction projects in Palestine: Contractors' perspective', Australasian Journal of Construction Economics and Building, 13 (2) 45-53 
Mahamid, I. (2011) 'Risk Matrix for Factors Affecting Time Delay in Road Construction Projects: Owners' Perspective', Engineering, Construction and Architectural Management, 8 (6), 609 617

Mahamid, I. and Bruland, A. (2012) 'Cost deviation in road construction projects: The case of Palestine', Australasian Journal of Construction Economics and Building, 12 (1), 58 - 71

Mahamid, I., Bruland, A. and Dmaidi, N. (2012) 'Delay causes in road construction projects', ASCE Journal of Management in Engineering, 28 (3), 300-310

Palstinian Contractor Union (PCU) Personal interview, March, 2011, Ramallah, The West Bank, Palestine

(PCBS/1) Palestinian Central Bureau of Statistics, The Palestinian economy performance, 2010, Palestine: Ramallah, PCBS, 2011, 43

(PCU/1) Palestinian Contractors Union, Construction Sector Profile. Palestine: West Bank, PCU, 2003

Sambasivan, M. and Soon, Y. (2007) 'Causes and effects of delays in Malaysian construction industry', International Journal of Project Management, 25 (5), 517-526

The U.S. Federal Highway Administration Office of International Programs (2007) Guide to the risk assessment and allocation process in highway construction, Report, July, 2007, Retrieved from http://international.fhwa.dot.gov/riskassess/images/riskmap.cfm, $10^{\text {th }}$ of April, 2012. 